\title{
Igen kis súlyú vagy 32. gesztációs hétnél éretlenebb koraszülöttek halálozási mutatói Magyarországon a EuroHOPE kutatás tükrében
}

\author{
Mihalicza Péter ${ }^{1}$ - Csákány György dr. ${ }^{2}$ - Szabó Miklós dr. ${ }^{3}$ \\ ${ }^{1}$ Semmelweis Egyetem, Doktori Iskola, Budapest \\ ${ }^{2}$ Minőségügyi szakfőorvos, szülészet-nőgyógyászat, Budapest \\ ${ }^{3}$ Semmelweis Egyetem, Általános Orvostudományi Kar, I. Gyermekgyógyászati Klinika, Budapest
}

\begin{abstract}
Bevezetés: Az 1500 gramm alatti súllyal vagy a 32. gesztációs hét előtt születettek ellátása magas szintú klinikai felkészültséget igényel, és megfelelő kezeléssel, ellátásszervezéssel a halálozási arány csökkenthető. Célkitüzés: A EuroHOPE projekt eredményeire építve a magyarországi és a nemzetközi halálozási kimenetelek, valamint a 2006-2008 közötti neonatalis ellátást jellemző hazai regionális különbségek bemutatása. Módszer: A Magyarországra vonatkozó adatokat a szülészeti regiszter és az Országos Egészségbiztosítási Pénztár finanszírozási adatbázisának összekapcsolásával állították össze. A különböző adatbázis-sajátságok, illetve szakmai alapú kizárások eredményeként 3562 újszülöttre vonatkozó adat került feldolgozásra. Eredmények: Magyarországon a kockázatkiigazított 365 napos halálozási arány szignifikánsan magasabb, mint a legtöbb vizsgált országban. A mortalitási kockázattal szoros összefüggést mutató betegségek Magyarországon fordulnak elő a leggyakrabban. Két megye halálozási adatai rosszabbak a modell alapján vártnál, egy esetében pedig jobbak. Következtetések: A hazai eredmények hátterében szisztematikus tényezők húzódhatnak meg. A szteroidprofilaxis alkalmazásának relatíve alacsony gyakorisága Magyarországon hozzájárulhatott a kedvezőtlenebb mortalitási értékekhez. Érdemes közös egyedi azonosítóval elősegíteni az érintett adatbázisok összekapcsolhatóságát. Orv. Hetil., 2016, 157(41), 1649-1656.
\end{abstract}

Kulcsszavak: csecsemő, igen kis súlyú, extrém koraszülött, halálozás, Magyarország

\section{Mortality rates of very low birth weight and very low gestational age newborns in Hungary. The EuroHOPE study}

Introduction: Care provision for very low birth weight and very low gestational age newborns requires high level clinical preparedness. Appropriate care and care management reduce mortality. Aim: To present Hungarian and international outcomes and local regional differences characterizing neonatal care in 2006-2008, based on the results of the EuroHOPE study. Method: Hungarian data were created by linking the obstetrics registry with the financing database of the Health Insurance Fund. Resulting from peculiarities of these databases and clinically justified exclusions, 3562 newborns were included. Results: Hungarian risk-adjusted 365-day mortality rate was significantly higher than in most of the studied countries. Incidence of diseases correlated with higher mortality risk was highest in Hungary. Mortality in two Hungarian counties was worse than expected based on modelling, while it was better in one county. Conclusions: Systematic factors might cause these results. Relatively low usage rate of steroid prophylaxis in Hungary might contribute to unfavorable mortality figures. A common unique identifier would help database linkage.

Keywords: infant, very low birth weight, extremely premature, mortality, Hungary

Mihalicza, P., Csákány, Gy., Szabó, M. [Mortality rates of very low birth weight and very low gestational age newborns in Hungary. The EuroHOPE study]. Orv. Hetil., 2016, 157(41), 1649-1656.

(Beérkezett: 2016. augusztus 1.; elfogadva: 2016. augusztus 25.) 


\section{Rövidítések}

$\mathrm{IVH}=($ intraventicular hemorrhage $)$ agykamrába törő vérzés; NEC $=$ (necrotizing enterocolitis) nekrotizáló enterocolitis; NIC $=$ neonatalis intenzív centrum; OEP = Országos Egész ségbiztosítási Pénztár; OGYEI = Országos Gyermekegészségügyi Intézet; PIC $=$ perinatalis intenzív centrum; RDS $=($ respiratory distress syndrome) respirációs distressz szindróma; ROP $=$ (retinopathy of prematurity) koraszülöttek ideghártyaelváltozása; taj - társadalombiztosítási azonosítójel; VLBW = (very low birth weight) 1500 gramm vagy az alatti születési súlyú, igen kis súlyú; VLGA = (very low gestational age) 32 . gesztációs hétnél éretlenebb

\section{A téma fontossága}

Világszerte nő az 1500 gramm alatti súllyal (very low birth weight - VLBW) vagy a 32. gesztációs hét előtt (very low gestational age - VLGA) születettek aránya. Ezek az újszülöttek fokozottan veszélyeztetettek, halálozási arányaik magasak. Ellátásuk magas szintű klinikai felkészültséget igényel mind a humán erőforrás, mind az eszközellátottság oldaláról a fogantatás előtt, a terhesség alatt és a megszületés után is. A csecsemóhalálozás mintegy $80 \%$-át ez a betegcsoport teszi ki. Megfelelő ellátással, ellátásszervezéssel a halálozási arány jelentősen csökkenthető, ezért fontos, hogy tisztában legyünk a magyarországi ellátás teljesítményével, az országon belüli esetleges különbségekkel. Az adatokból keletkező tudás révén tanulhatunk a hibákból és a sikerekből is. A továbbfejlődésre lehetôséget adó beavatkozási pontok azonosítását követően, jól megtervezett, az érintettek konszenzusán alapuló, célzott intézkedésekkel a szülészeti és neonatológiai ellátás továbbfejleszthető. Fontosnak tartjuk, hogy az újszülöttellátás folyamatáról, eredményességéről minél több, sokrétúbb és megbízható információ álljon rendelkezésre. Reményeink szerint jelen közlemény hozzájárul majd a bizonyítékokkal támogatott szakmai párbeszédhez.

\section{EuroHOPE projekt}

A nemzetközi összehasonlíthatóság érdekében a EuroHOPE projekt [1] egyik módszertani kiindulópontja volt, hogy esetszintű adatokat tartalmazó adminisztratív adatbázisokból dolgozik. Ez lehetővé tette, hogy az adatleválogatástól az adatfeldolgozásig minden lépés standardizált módon történjen (1.: jelen lapszám EuroHOPE módszertannal foglalkozó cikkét!). Ez a megközelítés biztosította az újszülöttek ellátórendszerbeli követhetőségét is. A nemzetközi kutatásban Magyarország mellett Finnország, Hollandia, Olaszország, Norvégia, Skócia és Svédország vett részt.

Az igen kis súlyú, illetve 32. gesztációs hétnél éretlenebb koraszülöttek adatfeldolgozásának eredményeiről a EuroHOPE projekt keretében már megjelent két angol nyelvű publikáció. Numerato és mtsai [2] a klinikai vonatkozásokra koncentráltak, míg Fattore és mtsai [3] az egészségügyi közgazdaságtan oldaláról közelítették meg a témát. Jelen cikkben a magyarországi vonatkozásokat emeljük ki.

\section{Módszer}

\section{EuroHOPE VLBW módszertan}

A vizsgált populáció a 2006. január 1. és 2008. december 31. között élve született, $1500 \mathrm{~g}$ és az alatti súllyal és/ vagy 32-nél kevesebb gesztációs hétre születettek. Kizárásra kerültek azok, akiknek érvénytelen volt az azonosítószámuk - esetünkben taj kapcsolati kódjuk -, valamint azok, akiknél olyan, halálhoz vezető veleszületett rendellenesség állt fenn, mint agyvelőhiány (BNO-10 Q00.0), kettős kiszájadzású jobb kamra (Q20.1), hypoplasiás bal szív szindróma (Q23.4), a vese agenesise, k.m.n. (Q60.2), a rekeszizom veleszületett rendellenességei (Q79.0, Q79.1), Patau-szindróma, k.m.n. (Q91.7) és Edwardsszindróma, k.m.n. (Q91.3). Szintén kizárásra kerültek a 22. gesztációs hét alatti és 39. gesztációs hét feletti koraés újszülöttek, továbbá azok, akiknél a súly és a gesztációs hét közötti jelentős ellentmondás tapasztalható (small or large for gestational age, Fenton és Kim 2013-as cikke [4] alapján), illetve akiknek az első kórházi esemény során a 99. percentilisnél hosszabb volt az ápolási idejük.

$\mathrm{Az}$ adatok rendelkezésre állása alapján, illetve összekapcsolhatósági problémák miatt Norvégia esetében a 2008-2009-es időszak, Hollandia esetében a 20062007-es időszak, míg Olaszország esetében csak Róma megye adatai kerültek elemzésre.

Az újszülöttek ellátórendszeri megjelenéseit a születést követő 365 napon belül követtük. Ez az egy év képezte a vizsgált teljes ellátási epizódot. A nemzeti adatbázisok adattartalma standardizált volt, ezekből a standard adattáblákból állítottak elő egységes leíró statisztikákat és regressziókat a központilag kidolgozott Stata kódok (1. jelen lapszám EuroHOPE módszertannal foglalkozó cikkét!).

A kockázatkiigazított halálozási arányokat úgy kaptuk meg, hogy a megfigyelt halálozások számát elosztottuk a várt halálozások számával, majd ezt a hányadost megszoroztuk az átlagos halálozási aránnyal. A halálozások várt számának becslése logisztikus regresszióval történt, amely a gesztációs időt (kategorikus változóként: $<25$. hét, 25-26. hét, 27-28. hét, 29-30. hét, 31-32. hét és $>32$. hét), az újszülött nemét, a méhen belüli növekedést (Fenton standardizált nemzetközi értékeit figyelembe véve), az 5 perces Apgar-értéket, az előző szülések számát és a többes szülés változókat vette figyelembe.

\section{Nemzeti adatbázis létrehozása}

Az esetek ellátórendszerben való követéséhez nélkülözhetetlen az Országos Egészségbiztosítási Pénztár (OEP) 
finanszírozási adatbázisa, míg szakmai szempontból a szülészeti statisztika jelenti a kiindulópontot. Ezenfelül felhasználtuk a taj passziválási törzset, amely a taj kapcsolati kódokhoz köthető esetleges halálozások időpontját tartalmazza, sajnos a halálok megjelölése nélkül. A halottvizsgálati bizonyítványon alapuló haláloki regiszter ugyan teljes körü és tartalmaz haláloki megjelölést is, ám csak 2015 óta tartalmaz taj-számot [5, 6]. Egyedi azonosító hiányában az újszülött adatain alapuló sztochasztikus (valószínúségi alapú) összekapcsolás rontotta volna a vizsgálat fó kimenetelét jelentő halálozási adatok megbízhatóságát.

\section{Az OEP-adatbázis előkészitése}

Az OEP adatbázisa nem teljes körü, mert csak a közfinanszírozott eseteket tartalmazza. Becslések szerint a szülések 3-4\%-a történik magánfinanszírozásban vagy nem intézményi keretek között [7]. Ezeket az eseteket elemzésünkben nem tudtuk figyelembe venni. Az újszülöttek beazonosításához azokat a fekvőbetegeseteket válogattuk le, ahol a születés dátuma és a felvétel dátuma között kevesebb mint 7 nap telt el, és az újszülött nem volt áthelyezett vagy visszahelyezett. Előfordulhat, hogy ugyanazzal a taj kapcsolati kóddal több ilyen felvétel is létezik, ekkor az adatbázisba az időben legkorábbi került bele. Kizárásra kerültek azok a rekordok, ahol a taj kapcsolati kód, a nem vagy az intézménykód érvénytelen volt.

\section{A Tauffer-adatbázis előkészitése}

A Tauffer-adatbázis a szülészeti eseményeket tartja nyilván a szülészeti osztályok jelentése alapján [7]. Az ikerszüléseket és így az ikrekre vonatkozó adatokat egy rekordban tárolja, a EuroHOPE projekt céljaihoz viszont ezek szétválasztására volt szükség. Az OEP-adatokkal való összekapcsolás is csak így lehetséges, ezért az ikerszülések esetében minden újszülöttre külön rekordot hoztunk létre. Kizártuk azokat az eseteket, ahol az újszülött vagy az anya születési ideje nem volt kitöltve, ahol a nem érvénytelen volt, illetve ahol a születési súly 150 gramm alatt volt.

Bár a Tauffer-féle az egyik legjobban töltött szakmai regiszter, de így sem teljes körü. A Központi Statisztikai Hivatal adatait [8] használva kontrollként, az érintett, 2006-2008 közötti időszakban a Tauffer-adatbázis az élveszületések 97\%-át tartalmazta.

\section{Az OEP-és a Tauffer-adatbázis összekapcsolásának menete}

Mivel itt több adatbázisról van szó, összekapcsolhatóságuk kulcskérdés. A betegek személyazonosításra nem alkalmas követése az OEP finanszírozási adatbázisában az ügynevezett taj kapcsolati kóddal lehetséges, a szülészeti események jelentése viszont nem tartalmaz a személyhez köthető egyedi azonosítót. Ennek következtében az adatbázisokban található közös, személyre vonatkozó mezők felhasználásával kellett valószínúsíthető rekordpárokat találni. Az összekapcsolás alapja az intézmény, a születési idő, a nem, a születési súly és az irányítószám volt. A Tauffer- és az OEP-adatbázisban található intézménykód nem ugyanaz, ehhez először egy kapcsolótáblát hoztunk létre, míg a többi változó kódolása megegyezett a két adatbázisban. Az összekapcsolás során a nagyon valószínú találatok felől haladtunk a bizonytalanabbak felé. Ez azt jelentette, hogy első körben az intézmény, a születési idő, a nem és a születési súly együttes, pontos egyezésével kerestünk OEP-Tauffer-párokat. Az így összepárosított rekordokat „félreraktuk”, és a még nem összekapcsolt rekordokkal folytattuk a keresést. A második körben a nem helyett az irányítószám egyezőségét követeltük meg, feltételezve, hogy az adatbeviteli hiba mértéke akár jelentős is lehet a nem esetében. A találatokat itt is „félreraktuk” és csak a maradékkal folytattuk. Az összekapcsolás találati arányát még tovább lehet növelni, ha a születési súly esetében $+/-5$ százalékos eltérést még megengedünk a két adatbázis között, illetve ha a születési idő esetében egy nap különbséget még elnézünk. Vannak olyan esetek, amelyek még az ilyen, lazított kritériumok mentén sem párosíthatók. Ilyenkor a Taufferben található anyai adatok alapján (intézménykód; az anya születési dátuma; az anya felvételi dátuma és az újszülött születési dátuma között kevesebb, mint hét nap a különbség; anya lakhelyének irányítószáma) megpróbáltuk megtalálni a szülőnóket az OEP fekvőbeteg-adatbázisában. Ez azért járható út, mert az anya rekordjának „kíséró törzsszáma” mezőjében sok esetben az újszülött születési rekordjához tartozó törzsszámot írják be. Az ily módon beazonosított OEP-újszülöttrekordok adatait összevetve a Tauffer-rekordokkal, az látszik, hogy az újszülött adatain alapuló algoritmusok a jelentősebb súlyeltérés miatt nem jártak sikerrel. Érdekesség, hogy ezek a súlykülönbségek csak nagyon kevés esetben keletkeztetnek más HBCs-besorolást, azaz nem finanszírozási „trükközés” a mögöttes ok.

Az 1. táblázatból látszik, hogy a Tauffer-regiszter és az OEP VLBW- és VLGA-rekordjai között a három vizsgált év átlagában 84\%-os összekapcsolási arányt sikerült elérni, ami az élveszületettek körében 89\%-ra nő. A párosított újszülöttek $82 \%$-ánál a két adatbázisban található minden fontosabb adat megegyezett, beleértve a születési súlyt is. A $89 \%$-os sikeresség nagyon kecsegtető, azonban a csecsemők születést követő egy éven belüli ellátási eseményeinek követéséhez végleges taj kapcsolati kódra van szükség. Ez azért jelent problémát, mert az újszülöttek kezdetben az anya taj-számából képzett ideiglenes taj-számot kapnak, a véglegeset csak később állítja ki az OEP. Sok esetben az újszülöttek már nem fekszenek bent az intézményben, amikor a végleges taj-szám előáll, így az intézmény az ideiglenes taj-számmal jelenti le az esetet az OEP felé. A későbbi esetleges ellátási ese- 
Tauffer-OEP fekvőbeteg-adatbázis összekapcsolásának alapadatai

\begin{tabular}{|c|c|c|c|c|}
\hline & 2006 & 2007 & 2008 & Összesen \\
\hline $\begin{array}{l}\text { A Tauffer-regiszterben található } \\
\text { VLBW- és VLGA-esetek száma } \\
\text { (ebból élveszületettek) }\end{array}$ & $\begin{array}{l}1879 \\
(1629)\end{array}$ & $\begin{array}{l}1925 \\
(1690)\end{array}$ & $\begin{array}{l}1878 \\
(1673)\end{array}$ & $\begin{array}{l}5682 \\
(4992)\end{array}$ \\
\hline $\begin{array}{l}\text { Ezen belül csak VLBW - } \\
1500 \text { g alatti, de } 32 \text {. hét } \\
\text { felettiek } \\
\text { (ebből élveszületettek) }\end{array}$ & $\begin{array}{l}325 \\
(291)\end{array}$ & $\begin{array}{l}323 \\
(290)\end{array}$ & $\begin{array}{l}311 \\
(277)\end{array}$ & $\begin{array}{l}959 \\
(858)\end{array}$ \\
\hline $\begin{array}{l}\text { Ezen belül csak } \\
\text { VLGA - } 32 . \text { hét alatti, } \\
\text { de } 1500 \text { gramm felettiek } \\
\text { (ebből élveszületettek) }\end{array}$ & $\begin{array}{l}339 \\
(312)\end{array}$ & $\begin{array}{l}355 \\
(333)\end{array}$ & $\begin{array}{l}393 \\
(372)\end{array}$ & $\begin{array}{l}1087 \\
(1017)\end{array}$ \\
\hline $\begin{array}{l}\text { Párosíthatók } \\
\text { (ebből élveszületettek) }\end{array}$ & $\begin{array}{l}1627 \\
(1501)\end{array}$ & $\begin{array}{l}1691 \\
(1554)\end{array}$ & $\begin{array}{l}1493 \\
(1405)\end{array}$ & $\begin{array}{l}4811 \\
(4460)\end{array}$ \\
\hline $\begin{array}{l}\text { Ezen belül: intézmény, } \\
\text { születési idő, nem, } \\
\text { születési súly megegyezik }\end{array}$ & 1361 & 1381 & 1205 & 3947 \\
\hline $\begin{array}{l}\text { Ezen belül: súly +/-5\%, } \\
\text { születési dátum }+/-1 \text { nap } \\
\text { ráhagyással, illetve nem } \\
\text { helyett irányítószám } \\
\text { használatával }\end{array}$ & 175 & 171 & 148 & 494 \\
\hline $\begin{array}{l}\text { Ezen belül: } \\
\text { anyán keresztül megtalált }\end{array}$ & 91 & 139 & 140 & 370 \\
\hline $\begin{array}{l}\text { Párosítható, élveszületett, } \\
\text { végleges taj kapcsolati kóddal } \\
\text { vagy indexepizódon belüli } \\
\text { elhalálozással }\end{array}$ & 1290 & 1285 & 1127 & 3702 \\
\hline $\begin{array}{l}\text { Ezen belül indexepizód során } \\
\text { meghalt }\end{array}$ & 131 & 189 & 157 & 477 \\
\hline $\begin{array}{l}\text { 99. percentilis miatti kizárások } \\
\text { után }\end{array}$ & 1248 & 1234 & 1080 & 3562 \\
\hline
\end{tabular}

mények során azonban már a végleges taj-számmal jelentik le az eseteket, ami semmilyen módszerrel nem kapcsolható az ideiglenes taj-hoz. A végleges taj kapcsolati kód beazonosítása végül az élveszületettek 74\%-ánál volt sikeres, azaz további 15\%-nyi esetet veszítettünk ennek az adminisztrációs sajátosságnak a következtében. A különböző kizárások eredményeként végül 3562 VLBWés VLGA-eset statisztikái kerültek kiszámításra.

Hangsúlyozni szeretnénk, hogy mind a Tauffer- és OEP-adatbázis közötti párosítás, mind a végleges taj kapcsolati kódok megtalálása csak sztochasztikus, azaz valószínúségi alapon történt, tehát a találatok helyessége csak feltételezhető. Biztos összekapcsolást csak egyedi azonosítókkal lehetne kivitelezni.

Az adattáblákat Oracle adatbázisban állítottuk elő, míg a részt vevő országok között standardizált statisztikai vizsgálatokhoz Stata 12 programcsomagot használtunk. A Stata egyes kimeneteit Microsoft Excellel elemeztük, valamint egyes ábrákat az $\mathrm{R}$ statisztikai program ggplot2 csomagjával készítettünk el.

\section{Eredmények}

A hét részt vevő országra vonatkozó részletes leíró statisztikák megtalálhatóak Numerato és mtsai már említett 2015-ös cikkében [2], ezért itt csak a Magyarország szempontjából érdekes eredményeket emeljük ki. Az alapadatokat vizsgálva kiderül, hogy a magyarországi kohorszban a legalacsonyabb a születési súly, az első szülések aránya, a 34 év feletti anyák részaránya, míg a leány újszülöttek részaránya a legmagasabb (2. táblázat [2]).

Az átlagos születési súlyt közelebbról vizsgálva megállapítható, hogy a magyar érték a holland, a skót és a svéd adatoknál szignifikánsan alacsonyabb, míg a finn, az olasz és a norvég értékektől nem különbözik (1. ábra [2]).

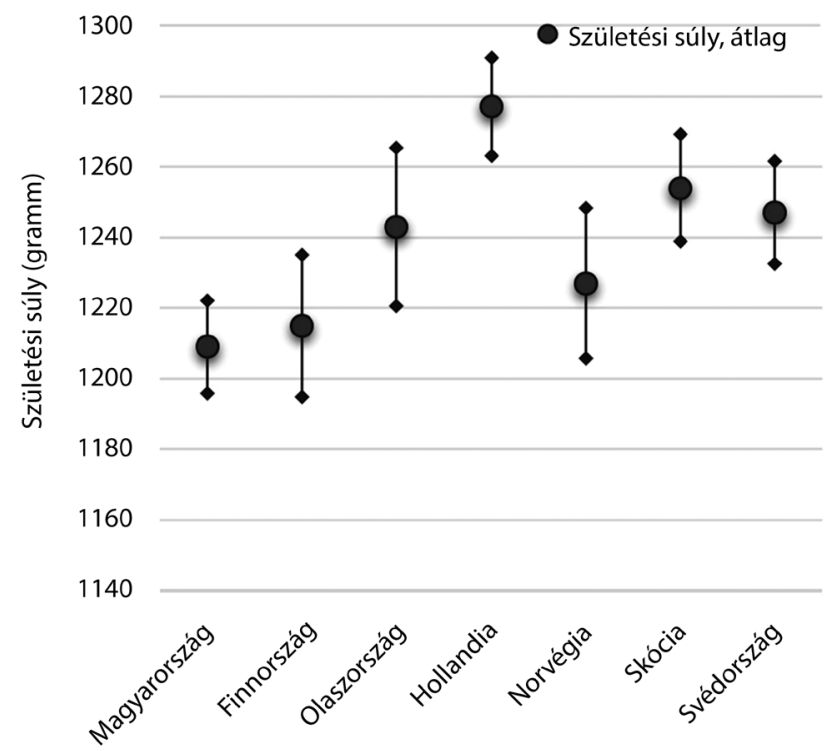

\begin{tabular}{l|l} 
1. ábra & Átlagos születési súly és a 95\%-os megbízhatósági szinthez tar-
\end{tabular} tozó konfidenciaintervallum az egyes EuroHOPE országokban

2. táblázat | Egyes kiemelt mutatók nemzetközi összehasonlításban

\begin{tabular}{|c|c|c|c|c|c|c|c|}
\hline & Magyarország & Finnország & Olaszország & Hollandia & Norvégia & Skócia & Svédország \\
\hline $\begin{array}{l}\text { EuroHOPE-számításokban } \\
\text { szereplő újszülöttek száma }\end{array}$ & 3562 & 1455 & 1265 & 2628 & 1311 & 2330 & 3137 \\
\hline Átlagos születési súly, gramm (SD) & $1209(400)$ & $1215(392)$ & $1243(407)$ & $1277(362)$ & $1227(391)$ & $1254(372)$ & $1247(414)$ \\
\hline $\begin{array}{l}\text { Leányok részaránya a VLBW- és } \\
\text { VLGA-újszülöttek között, \% }\end{array}$ & 49,1 & 45,3 & 46,2 & 44,9 & 45,2 & 46,4 & 44,5 \\
\hline Első szülések aránya, \% & 51,5 & 52,4 & 66,7 & 62 & 53,8 & 58,3 & 83,5 \\
\hline 34 év feletti anyák részaránya, \% & 19,6 & 30,3 & 42,4 & 20,6 & 27,4 & 22,5 & 26,1 \\
\hline
\end{tabular}




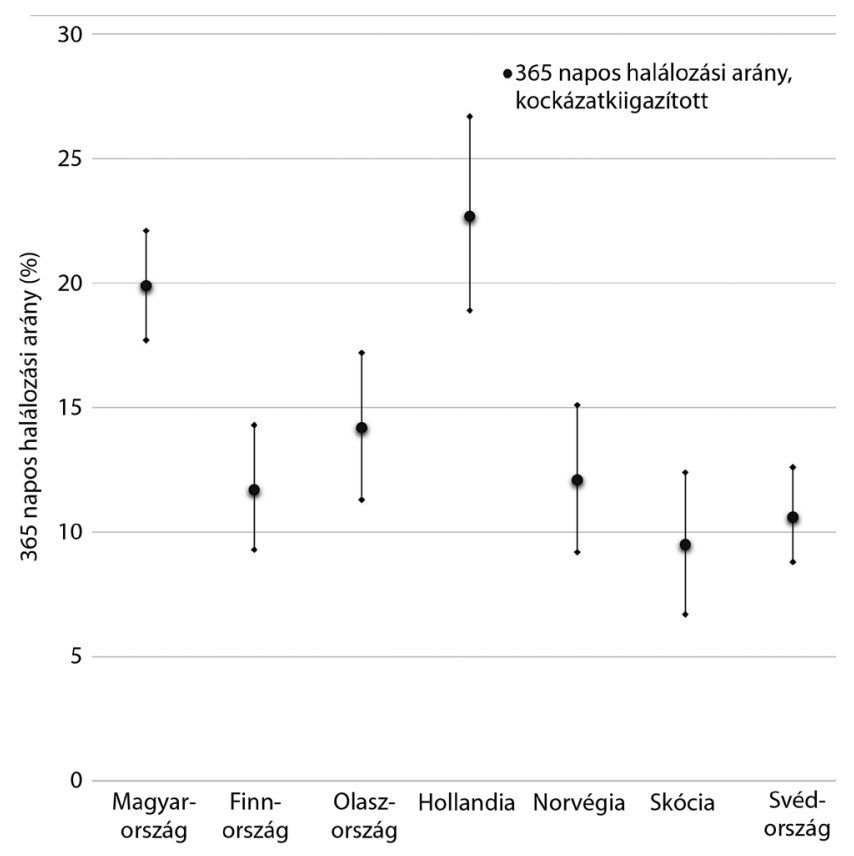

2. ábra

Kockázatkiigazított 365 napos VLBW és VLGA halálozási arányok az egyes EuroHOPE országokban, 2006-2008. A kockázatkiigazítás a gesztációs időt, a csecsemő nemét, a méhen belüli növekedést, az 5 perces Apgar-értéket, az előző szülések számát és a többes szülés változókat vette figyelembe

Az eredeti kutatás legfontosabb kimeneti változója a halálozási arány volt, amelyet a születést követő 7, 30, 90 és 365 napra is vizsgált a nemzetközi munkacsoport. Jelen közleményben a 365 napos halálozási arányra fogunk koncentrálni. A 2. ábrán [2] azt láthatjuk, hogy Magyarországon a kockázatkiigazított 365 napos halálozási arány 19,9\%. Ez - 95\%-os megbízhatósági szinten szignifikánsan magasabb, mint a finn, olasz, norvég, skót és svéd halálozási ráták. Statisztikai értelemben nincs eltérés a holland adatoktól, bár maga a becsült átlagérték Hollandiában magasabb.

A nemzetközi összehasonlításban kedvezőtlenebb magyar halálozási mutató részletesebb, gesztációs korcsoport szerinti vizsgálata nyomán kiderül, hogy - Hollandia és Olaszország kivételével - minden gesztációs kor esetén a hazai érték a legmagasabb a vizsgált országok között (3. táblázat [2]). Érdekes, hogy Olaszországhoz viszonyítva a 27 . hét előtti nyers halálozási arányok vala- mivel alacsonyabbak Magyarországon, míg az e feletti gesztációs korcsoportoknál magasabbak.

Hasonlóképpen, a megszületéssel kapcsolatos első kórházi epizód során diagnosztizált, a mortalitási rizikóval szoros összefüggést mutató betegségek Magyarországon gyakrabban fordulnak elő, mint a többi vizsgált országban (3. ábra).

A vizsgált hazai adatokból kiderül, hogy az újszülöttek 90\%-a PIC-cel rendelkező intézményben született, míg 8\%-uk nem a számukra optimális intézményben vagy helyszínen jött világra ( $2 \%$ nem volt besorolható).

A 4. ábrán a megyénkénti, kockázatkiigazított csecsemőhalálozási arányokat ábrázoltuk egy tölcsérgrafikonon. Spiegelhalter 2005-ben publikált cikke szerint [9] a tölcsérgrafikon alkalmas annak megállapítására, hogy az elemzési egységek - esetünkben megyék - indirekt standardizálással számolt kimeneti mutatóinak értéke szignifikánsan különbözik-e egytől - azaz attól az esettől, ahol a megfigyelt és a várt halálozás megegyezik. Az ábrából megállapíthatjuk, hogy két megyében a 365 napos VLBW- és VLGA-halálozás a modellbe bevont változók alapján vártnál másfélszer nagyobb, ami szignifikáns különbség a többi megye eredményéhez képest. Ugyanakkor egy megye esetében a ténylegesen meghaltak száma nagyjából fele a modell alapján várhatóhoz képest, ami szignifikánsan kedvező eredmény.

\section{Megbeszélés}

A szerzők tudomása szerint ez az első olyan tanulmány, amely a magyarországi VLBW- és VLGA-újszülöttek 365 napos halálozását nemzetközi összehasonlításban vizsgálta. Az elsődlegesen finanszírozásra szolgáló OEPadatállománynak és a szülészeti események jelentésének (Tauffer-adatbázis) összekapcsolásából a koraszülöttek 74\%-a volt bevonható a vizsgálatba. Ennek elsődleges oka az újszülötteknek adott ideiglenes taj-számmal kapcsolatos követhetőségi probléma, másodlagos oka a Tauffer- és az OEP-adatbázis közötti közös, egyedi azonosító hiánya. Az adatok nem teljes körű volta óvatosságra int az eredmények értékelésekor. Felmerülhet, hogy az elemzésből kimaradó esetek körében az átlagos halálozás lényegesen eltér a bennmaradó esetekétől, azaz szisztematikus torzítás lép fel.

3. táblázat | Gesztációs korcsoportok szerinti 365 napos nyers halálozási arányok (\%), 2006-2008

\begin{tabular}{|c|c|c|c|c|c|c|c|}
\hline Gesztációs korcsoport & Magyarország & Finnország & Olaszország & Hollandia & Norvégia & Skócia & Svédország \\
\hline$<25$. hét & 77,7 & 65,9 & 77,8 & 85,4 & 63,3 & 59 & 48,8 \\
\hline 25-26. hét & 40 & 24,9 & 42,2 & 40,3 & 17,4 & 18,8 & 17,2 \\
\hline 27-28. hét & 16 & 13,9 & 13,5 & 16,2 & 8,2 & 6,2 & 7,6 \\
\hline 29-30. hét & 8 & 3,5 & 5,6 & 9,2 & 5,2 & 1,4 & 3,3 \\
\hline 31-32. hét & 3,9 & 1,8 & 3,6 & 4,1 & 2,2 & 1,4 & 2,5 \\
\hline$>32$. hét & 7,7 & 2,1 & 2,8 & Nem közzétehető* & 7,7 & 1,6 & 4,1 \\
\hline
\end{tabular}

*A kategóriába eső alacsony esetszám miatt a halálozási arány megbízhatóan nem számolható ki. 

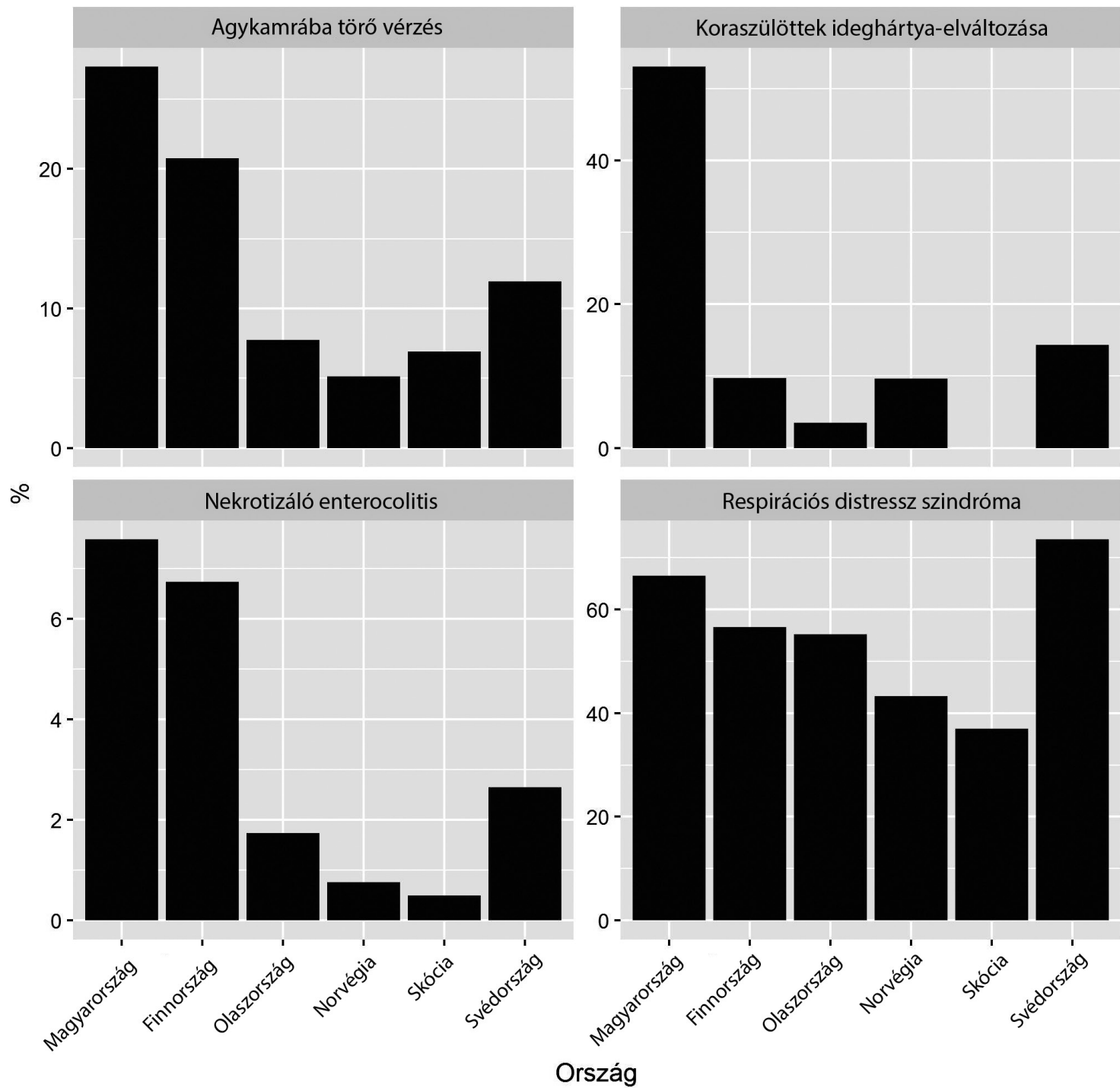

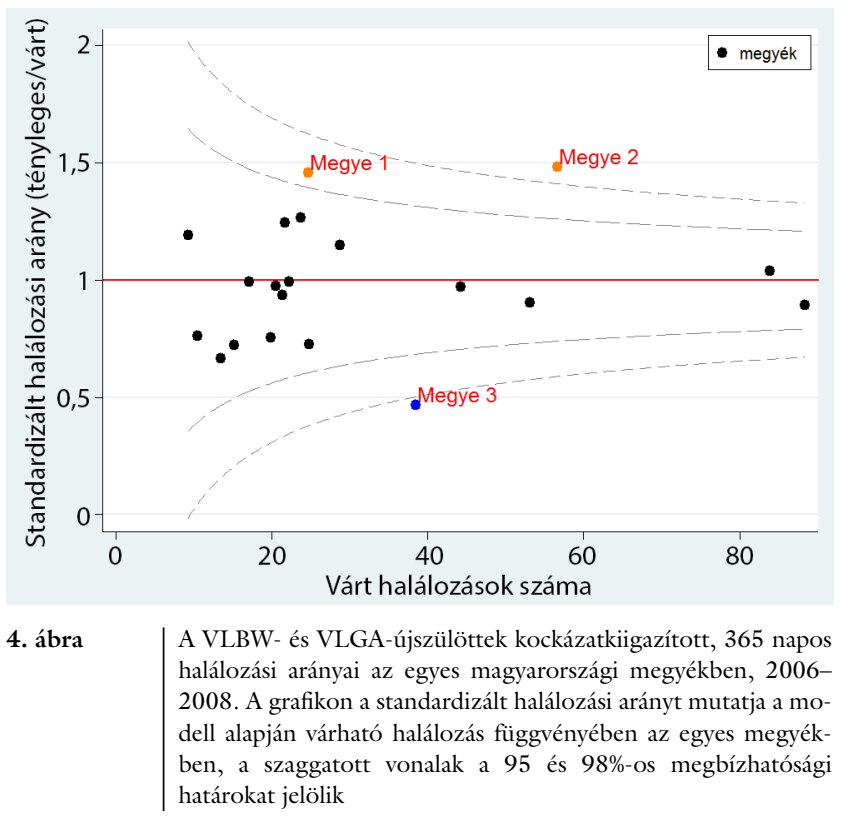

A magyarországi adatok esetében a kiindulópontul szolgáló 4992 VLBW- és VLGA-eset 1,68\%-os incidenciát jelent az összes élve született vonatkozásában. Csak a 3975 VLBW-esetet figyelembe véve ez 1,34\%. Az EuroPeristat 2004-es adatai szerint Magyarországon a VLBW-esetek az összes élve született 1,4\%-át [10], míg a KSH 2010-re vonatkozó adata szerint 1,45\%-át [11] teszik ki. Az Országos Gyermekegészségügyi Intézet (OGYEI) Neonatalis Intenzív Centrum (NIC) adatbázisának 2005-2009-es időszakról szóló összegző jelentésében [12], amely 21 NIC tevékenységéról szóló adatokat elemzi, évente átlagosan 1160, 1500 gramm alatti és 1185,32 . gesztációs hét előtti koraszülött volt. Az 1500 gramm alattiak 18,2\%-a, a 32 . gesztációs hét előtt születettek $17,9 \%$-a halt meg a kórházi benntartózkodás alatt. Mindezek alapján megállapítható, hogy a jelen elemzésben tapasztalt eredmények nagymértékú hasonlóságot mutatnak a más módszerrel gyújitött és másutt korábban publikált hazai eredményekkel. Ez arra enged következ- 
tetni, hogy a vizsgált időszakban a finanszírozásra szolgáló adatokból is számos értékes és releváns információt lehet előállítani a vizsgált populációval kapcsolatban.

A VLBW- és VLGA-újszülöttek körében az átlagos születési súly Magyarországon szignifikánsan alacsonyabb, mint a holland, skót és svéd érték. Ennek oka lehet egyrészt az extrém éretlen koraszülöttek élve vagy halva szülöttként való regisztrálása, másrészt pedig a súlyhoz kötött HBCs-finanszírozás esetleges torzító hatása.

Magyarországon a VLBW- és VLGA-újszülöttek közötti 365 napos halálozási ráta szignifikánsan magasabb a finn, norvég, skót és svéd adatoknál, míg statisztikai értelemben nincs eltérés az olasz és a holland adatoktól. A koraszülöttek halálozási kockázata szoros összefüggésben áll az éretlenség fokával. Emiatt egy adott országban a VLBW és VLGA miatti halálozási arányt nagymértékben befolyásolhatja a csoporton belül az alacsonyabb gesztációs idejü, igen éretlen koraszülöttek esetleges nagyobb száma és aránya. A jelen összehasonlításban az az eredmény, hogy Magyarországon minden gesztációs korú kohorszban magasabb halálozási arány mutatkozott az összehasonlításban szereplő hét országból öthöz képest, arra utal, hogy a hazai magasabb halálozási kockázat nem látszólagos, nem a fentebb említett esetleges torzító hatások következménye, hanem valódi különbséget jelez, amelynek hátterében szisztematikus tényezők húzódhatnak meg.

Ezt a megállapítást erősíti, hogy Magyarországon gyakrabban diagnosztizálnak a vizsgált koraszülött-populációban a halálozási kockázatot növelő betegségeket (IVH, NEC, RDS, ROP), mint a többi vizsgált országban. Ennek az összehasonlításnak azonban számos limitációja van. A vizsgálat tárgyát képző diagnózisoknak nem volt előre meghatározott egységes definíciója, és elsősorban a hazai adatgyüjtés vonatkozásában bizonytalan, hogy az adott betegség milyen súlyossági fokot jelöl. Mindezek a tényezők jelentősen hozzájárulhattak a mortalitási kockázatot növelő betegségek nemzetközi összehasonlításban kiugróan magas különbségeihez. Ugyanakkor az újszülöttkori halálozás közel felére csökkenthető (relatív rizikó: 0,55; 95\%-os konfidenciaintervallum: $0,43-0,72)$ a fenyegető koraszülés esetén alkalmazott antenatalis szteroidprofilaxissal. A terápia csökkenti az RDS, az IVH és a NEC kockázatát, és az egyszeri kezelésnek az anyára, illetve rövid távon a magzatra nincs igazolható nemkívánatos hatása. Alkalmazása a 34. terhességi hét előtt fenyegető koraszülésnél minden esetben javasolt [13]. Az OGYEI 2005-2009-es adatokon alapuló jelentése [12] szerint: „Az egyértemú szakmai ajánlás ellenére országosan a NIC-ek tudomására jutott, protokoll szerint végzett teljes antenatalis szteroidprofilaxis a 34. gesztációs hét előtt született koraszülöttek csupán 27,7\%-ánál történt meg, további 7\%-uknál pedig részleges szteroidprofilaxis történt. Az ápoltak 22,1\%-áról nem áll rendelkezésre ez az adat, és ismereteink szerint $43,2 \%$-ban az anya nem kapott antenatalis szteroidot." A szteroidprofilaxis alkalmazásának relative alacsony gyakorisága Magyarországon önmagában is jelentős mértékben hozzájárulhatott a kedvezótlenebb mortalitási eredményhez. További lehetséges meghatározó tényező lehet, hogy a nôvérlétszám a vizsgált országok között a legalacsonyabb, illetve, hogy a vizsgált 3 évben az orvostechnikai szinvonal viszonylag alacsony volt (Prof. Dr. Machay Tamás közlése).

A hazai regionális, megyei különbségeket vizsgálva kiderült, hogy két megyében a VLBW és VLGA miatti 365 napos halálozási arány a kockázatkiigazítást követően is szignifikánsan kedvezőtlennek mondható, míg egy harmadik megyénél szignifikánsan kedvező eredményt tapasztaltunk. A kimutatott megyei eredmények különbsége ismételten rámutat arra, hogy a magyarországi gyógyítási eredményekben számottevő regionális különbségek vannak, amelyek további, részletesebb elemzésre érdemesek.

\section{Adatbázisokkal, adatokkal és azok felhasználásával kapcsolatos következtetések}

Ahhoz, hogy a VLBW- és VLGA-újszülöttek ellátásával és gyógyítási eredményeivel kapcsolatos monitorozás és nemzetközi összehasonlítás rendszeressé válhasson, a gyüjtött információknak nemzetközi konszenzusra épülő adatdefiníciókon kell alapulniuk, és az adatlekérdezések minél magasabb fokú automatizálhatóságára van szükség. Ehhez célszerú lenne elérni a regiszterek, a haláloki statisztika és a finanszírozási adatbázisok közötti, szabályozott, etikai jóváhagyáshoz kötött, egyedi azonosítón alapuló összekapcsolhatóságot, illetve az újszülöttek ideiglenes és végleges taj-száma közötti megfeleltethetőséget.

A halálozási mutatók vizsgálata nem teszi lehetővé a jelentős, életminőséget rontó, de halállal nem járó megbetegedések hatásainak vizsgálatát [14]. A jövőben a VLBW- és VLGA-újszülöttek gyógyítási minőségének méréséhez a nyers mortalitási és morbiditási mutatókon felül a hosszú távú kimenetel monitorizálására is szükség lesz. Ehhez a fentebb említett adatbázisokon felül az iskoláskorra vonatkozó testi és szellemi fejlettséget leíró adatbázisokkal (KIR) való kapcsolat és kutathatóság megteremtése is szükséges.

A monitorozás azonban nem sokat ér az eredmények értelmezése nélkül. A számszerű eredmények értékelése, magyarázata, az indikátoreredményeket torzító környezeti sajátságok figyelembevétele a téma szakértőinek feladata. Meggyőződésünk, hogy csak a kvantitatív és a kvalitatív megközelítések együttes alkalmazása vezethet az ellátás minőségének tényleges fejlesztéséhez.

A EuroHOPE projekt koraszülöttekkel kapcsolatos feladatainak fontos tapasztalata, hogy a nemzetközileg összehasonlítható adatok előállítása már önmagában, az elemzést megelőzően kihívást jelentett az egyes nemzeti adatbázisok összekapcsolhatóságának hiányosságai miatt. 
A részt vevő skandináv országok kivételével ez mindenütt problémákat okozott.

Mivel az itt elemzett adatok közel 10 évesek, fontosnak tartjuk megjegyezni, hogy a vizsgálat idejéhez képest Magyarországon 5,6 ezrelékről 2015-re 4,1 ezrelékre csökkent a csecsemőhalandóság [8], ami azt sejteti, hogy a perinatalis ellátásban számottevő javulás állt be. Ennek okai a következők lehetnek. 2014-2015 folyamán 5,5 milliárd forint értékű eszközberuházás valósult meg a hazai PIC-ekben. A morbiditást és mortalitást jelentősen csökkentő antenatalis szteroidprofilaxist a 34. gesztációs hét előtt született koraszülöttek körében az elmúlt évtizedben sikerült megduplázni az OGYEI PIC-adatbázis 2013-as jelentése szerint [15]. Továbbá rohamosan terjednek az evidenciaalapú noninvazív ellátási formák, mint amilyen az nCPAP- (nasal continuous positive airway pressure) kezelés is [16].

A jövőben a VLBW- és VLGA-koraszülöttek mortalitás- és morbiditásarányainak rendszeres, hosszú távú vizsgálata és mélyebb elemzése elengedhetetlen az egészségügyi beruházások és szakmai intervenciók megtervezéséhez és hatásának méréséhez, valamint a regionális egyenlőtlenségek felszámolásához.

Anyagi támogatás: M. P. és Cs. Gy. a közlemény alapját képező ismeretek összegyújtéséért az Európai Unió 7. keretprogramjának 241721. számú szerződése szerint a European Health Care Outcomes, Performance and Efficiency (EuroHOPE) projekt keretében anyagi támogatásban részesültek.

Szerzői munkamegosztás: M. P.: A kézirat vázának összeállítása és első változatának megszövegezése, a részkutatás hazai irányítása. Cs. Gy., Sz. M.: A kézirat orvosszakmai tartalmának összeállítása, véleményezése, kiegészítése. A cikk végleges változatát valamennyi szerző elolvasta és jóváhagyta.

Érdekeltségek: M. P. és Cs. Gy. a 2013-ban zárult EuroHOPE kutatási projektben aktívan részt vett.

\section{Köszönetnyilvánítás}

A szerzők köszönetet mondanak Németh Évának a kézirattal kapcsolatos értékes szerkesztői észrevételeiért. Hálásak vagyunk $D r$. Valek Andreának, hogy közremúködött az Országos Gyermekegészségügyi Intézet adatainak rendelkezésre bocsátásában.

\section{Irodalom}

[1] Häkkinen, U., Iversen, T., Peltola, M., et al.: Health care performance comparison using a disease-based approach: The EuroHOPE project. Health Policy, 2013, 112(1-2), 100-109.
[2] Numerato, D., Fattore, G., Tediosi, F., et al.: Mortality and length of stay of very low birth weight and very preterm infants: A EuroHOPE study. PloS ONE, 2015, 10(6), e0131685.

[3] Fattore, G., Numerato, D., Peltola, M., et al.: Variations and determinants of mortality and length of stay of very low birth weight and very low for gestational age infants in seven European countries. Health Econ., 2015, 24(Suppl. 2), 65-87.

[4] Fenton, T. R., Kim, J. H.: A systematic review and meta-analysis to revise the Fenton growth chart for preterm infants. BMC Pediatr., 2013, 13, 59.

[5] Decree No. 34/1999 (IX. 24) of BM-EüM-IM on the execution of the provisions of act CLIV of 1997 on health care concerning the dead and the procedures in case of unexpected death. [34/1999. (IX. 24.) BM-EüM-IM együttes rendelet az egészségügyről szóló 1997. évi CLIV. törvénynek a halottakkal kapcsolatos rendelkezései végrehajtásáról, valamint a rendkívüli halál esetén követendő eljárásról.] 1999. http://www.njt.hu/ cgi_bin/njt_doc.cgi?docid=40386.62010 [Hungarian]

[6] Government Decree No. 351/2013. (X. 4) on autopsy and the procedures concerning the dead. [351/2013. (X. 4.) Korm. rendelet a halottvizsgálatról és a halottakkal kapcsolatos eljárásról.] 2013. http://net.jogtar.hu/jr/gen/hjegy_doc.cgi?docid= Al300351.KOR [Hungarian]

[7] Csákány, M. Gy.: Past, present, future and benefits of "Tauffer", the Hungarian obstetric registry. [A „Tauffer”, a magyar szülészeti regiszter múltja, jelene, jövője és haszna.] Orv. Hetil., 2014, 155(19), 750-754. [Hungarian]

[8] Central Statistical Office: Population, demographics (1941-). [Központi Statisztikai Hivatal: Népesség, népmozgalom (1941-).] http://www.ksh.hu/docs/hun/xstadat/xstadat_eves/ i_wnt00lb.html [Hungarian]

[9] Spiegelhalter, D. J.: Funnel plots for comparing institutional performance. Stat. Med., 2005, 24(8), 1185-1202.

[10] EURO-PERISTAT: European Perinatal Health Report. 2008. http://lara.inist.fr/handle/2332/1482

[11] Central Statistical Office: Infant mortality in Hungary. [Központi Statisztikai Hivatal: Csecsemőhalandóság Magyarországon.] Statisztikai Tükör, 2011, 5(70). [Hungarian]

[12] Páll, G., Valek, A., Szabó, M.: Activity of Neonatal Intensive Care Units, 2005-2009. [A Neonatális Intenzív Centrumok tevékenysége 2005-2009.] Országos Gyermekegészségügyi Intézet, Budapest, 2011. [Hungarian]

[13] Roberts, D., Dalziel, S.: Antenatal corticosteroids for accelerating fetal lung maturation for women at risk of preterm birth. Cochrane Database Syst. Rev., 2006, (3), CD004454.

[14] Balla, Gy., Szabó, M.: Chronic morbidities of premature newborns. [Koraszülöttek krónikus utóbetegségei.] Orv. Hetil., 2013, 154(38), 1498-1511. [Hungarian]

[15] Valek, A., Szabó, M.: Report on newborns nursed in Neonatal Intensive Care Units, 2013. [Jelentés a Neonatális Intenzív Centrumokban ápolt újszülöttekról 2013.] Országos Gyermekegészségügyi Intézet, Budapest, 2015. [Hungarian]

[16] Valek, A., Jermendy, Á., Szabó, M.: PIC III in Hungary, First National clinical audit 2005-2013. [Magyarországi PIC III., I. Országos orvosszakmai audit 2005-2013.] Magyar Perinatológiai Társaság Kongresszusa, Várgesztes, 2014. [Hungarian]

(Mihalicza Péter,

Budapest, Kőhalom u. 2., 1118 e-mail: peter.mihalicza@gmail.com) 